\title{
Financial reforms and credit growth in Nigeria: empirical insights from ARDL and ECM techniques
}

\section{Ngozi Adeleye, Evans Osabuohien, Ebenezer Bowale, Oluwatoyin Matthew \& Emmanuel Oduntan}

To cite this article: Ngozi Adeleye, Evans Osabuohien, Ebenezer Bowale, Oluwatoyin Matthew \& Emmanuel Oduntan (2017): Financial reforms and credit growth in Nigeria: empirical insights from ARDL and ECM techniques, International Review of Applied Economics, DOI: 10.1080/02692171.2017.1375466

To link to this article: http://dx.doi.org/10.1080/02692171.2017.1375466

\section{Published online: 10 Oct 2017.}

Submit your article to this journal $₫$

Q View related articles $\sqsubset$

View Crossmark data \lceil 


\title{
Financial reforms and credit growth in Nigeria: empirical insights from ARDL and ECM techniques
}

\author{
Ngozi Adeleye, Evans Osabuohien, Ebenezer Bowale, Oluwatoyin Matthew and \\ Emmanuel Oduntan
}

Department of Economics and Development Studies, Covenant University, Ota, Nigeria

\begin{abstract}
In the last 37 years, Nigeria has undergone several stages of financial reforms with different impacts on the economy. This paper analyses the impact of these financial reforms on credit growth in Nigeria using annual data from 1980 to 2016. The research work hinges on the theoretical underpinning of McKinnon-Shaw hypothesis on the relevance of financial reforms in a lagging economy. Analysing the data with autoregressive distributed lag error correction representation and bounds testing techniques, we find evidence supporting this hypothesis, and specifically that at higher real interest rates there is increased financial intermediation evidenced by credit growth. Other findings are that in the long-run, financial system deposits, inflation rate and per capita GDP are strong asymmetrical predictors of credit growth and real interest rates (the financial reform indicator), while the short-run relationships are indicator-specific. We further show that a long-run cointegration relationship exists between domestic credit and other covariates and likewise between the real interest rate and its regressors.
\end{abstract}

\section{ARTICLE HISTORY}

Received 25 April 2017

Accepted 31 August 2017

\section{KEYWORDS}

Autoregressive distributed lag; bounds testing; cointegration; credit growth; financial reform; interest rate

\section{JEL CODES}

E43; E44; G18; G21

\section{Introduction}

Financial reform is the process of moving towards market-determined rates of interest, as well as market-determined prices, as opposed to government-regulated rates of interest (known as an interest rate ceiling). McKinnon (1973) and Shaw (1973) expounded the dangers of a repressive financial system on the economies of developing countries, arguing that repression is inimical to economic growth. They consider financial liberalisation or deepening to be the backbone of economic reforms in lagging economies (Balassa 1990) and explain it to mean the creation of higher interest rates that equate the demand and supply for savings, and argued that increased rates of interest would lead to increased saving, increased financial activities (i.e. financial intermediation) and a more efficient use of savings (i.e. generating credits). Both agree that capital flight will occur once the real rate of return falls below the equilibrium rate due to rising inflation. That is, domestic savers will 
have no incentive to increase the stock of funds available for domestic investment (shifting preference for the acquisition of real assets) which in turn affects economic growth.

Financial sector reforms in Nigeria can be said to begin substantially in 1986 during the launch of the Structural Adjustment Programme, a fallout from the International Monetary Fund (IMF) loan conditionality (Osabuohien 2008; Omankhanlen 2012; Osuagwu and Nwokoma 2017). The first was termed 'exchange rate reforms' which led to the creation of the first-tier and second-tier (autonomous) foreign exchange markets. The second stage of the reforms classified as 'interest rate and monetary policy reforms' commenced in 1987 until 1996 with the liberalisation of interest rates, and the introduction of the auction market for government securities in 1989 as well as the continued use of cash reserve requirements, that is, direct monetary policy instruments (Edo 2012; Omankhanlen 2012; Orji, Aguegboh, and Anthony-Orji 2015). The third stage was the banking and capital market reforms in 1987 with the deregulation of bank licencing; this policy led to the rapid increase in banks from 41 in 1986 to 120 by 1992. From 1988 to 2005, the banking system went through transitional processes with the reduction of the number of banks from 89 to 25 and the increase in the minimum capital base from N2billion to N25billion (Egwakhe and Osabuohien 2009; Adelakun 2010; Shittu 2012). Lastly, in 2010 was a number of reforms including abolishing universal banking, the creation of the Asset Management Company tasked with buying out banks 'toxic assets' and the comprehensive review of provisional guidelines for margin loans. However, the reforms progress came not without hiccups (Olofin and Afangideh 2008; Omankhanlen 2012) at the initial stages but later led to improvements in financial indicators and economic growth. One of the favourable outcomes of the liberalisation process was the increase in bank credits to the private sector, as economic growth and development hinges on the extent to which household and firms have access to credit. ${ }^{1}$

Statistics from World Development Indicators of the World Bank (2017) indicate that the share of the banking system's credit to the private sector improved significantly from $34 \%$ in the 1980 s on the average to about $49 \%$ in the 1990 s and early part of 2000 . The bulk of the credit to the private sector was mainly on short-term investment. The depth of the financial sector measured by the ratio of broad money supply to gross domestic products (M2/GDP), contrary to expectation, did not improve in the 1990s as a decline was recorded from $32.6 \%$ on the average in the 1980 s to $26 \%$. In 2006 , the financial sector deepened with an increase in M2/GDP ratio from $16.4 \%$ at the end of 2005 to $16.9 \%$ in 2006. The banking system's capacity to finance economic activity was strengthened with a higher ratio of credit to the private sector to GDP than the preceding year. The ratio of credit to the private sector to GDP was 23.1\% at the end of 2006 (Bassey, Bessong, and Effiong 2012).

Thus, this study contributes to the literature by testing the McKinnon (1973) and Shaw (1973) hypothesis on Nigeria's financial reforms. Given that financial reforms embodies several components such as interest rate deregulation, removal of credit controls, removal of excessive reserve requirements, relaxation of entry, capital control deregulation, and so on, studies have used a dummy variable or any of these indicators (where financial reform index is not available) to proxy financial reform. Thus, we use the real interest rate as the financial reform variable in examining the impact on credit growth (a measure of financial system stability). One of the policy implications will be to guide financial regulators in understanding the extent to which the financial intermediaries, and economic agents (individuals, households and firms) respond to credit access given the direction of interest rate. The rest of this paper is organised as follows: Section 2 reviews the literature, Section 3 
describes empirical methods, the results are presented and discussed in Section 4 while Section 5 concludes with policy implications.

\section{Brief insights from extant literature}

Both the theoretical and empirical literature have been consumed with testing the McKinnon (1973) and Shaw (1973) hypothesis, to evaluate its applicability. One of the salient points of their hypothesis is the impact of higher interest rate on both lenders and borrowers. According to them, savers and investors will operate in accordance with market dictates once the financial system shifts away from repression to reform. This is because an interest rate ceiling creates a wedge between social and private returns, distorting intertemporal returns, which shifts savings towards the acquisition of real assets (such as land, gold), in addition to creating a bias towards current consumption.

There are contrary views on the effects of financial reforms. In this school of thought Wijnbergen (1982) and Taylor (1988) state that high interest rates may hamper financial deepening and hinder the economic growth of developing economies. They argue that a high interest rate has both positive and negative impacts depending on who the financial dealer is. To the lender, such a rate is advantageous and will create the drive for more savings with the bid to earn more interest income while a high interest rate discourages access to loans thereby causing disinvestment in the real sector. Thus, the net effect of a high interest rate is excess liquidity within the financial system which creates a huge interest payment obligation on financial intermediaries irrespective of their ability to create or generate corresponding credit. However, despite the arguments against financial reform, the populist opinion (also supported by the IMF and World Bank) is that the gains from financial reforms outweigh that from a repressive financial system.

Empirical results on the impact of financial reform vary, given the usage of different proxy indicators in addition to different methodologies adopted. On Iraq, Khalaf (2011) finds that interest rate deregulation stimulates financial deepening, encouraging savings and increases financial assets in the long-run, but such may not be the case in the short-run. Chandar, Patro, and Yezegel (2009) and Chung, Smith, and Wu (2009) find that financial reform encourages savers and borrowers to operate in accordance with the dictates of market forces which would engender healthy competition and promote financial market efficiency. Orji, Aguegboh, and Anthony-Orji (2015) find that financial liberalisation (proxied by domestic credit) promotes real sector activities. On Nigeria, Akingunola et al. (2013) find that financial liberalisation proxied by the ratio of liquid liabilities, real interest rate and total deposits does not significantly impact economic growth. Recent studies in Nigeria that used micro-level analyses include: Efobi, Osabuohien and Oluwatobi (2014) and Efobi, Beecroft and Osabuohien (2014). The former surmised the need for commercial banks to go beyond acting as agent for remittance collection, to incorporate advisory roles for their customers, which will increase bank breadth; the latter used the World Bank Household Survey on financial inclusion to investigate the factors that can influence access to and use of bank services in Nigeria.

On the Ghanaian economy, Adam (2011) using a financial liberalisation index constructed using the Principal Component Analysis finds positive and long-run relationships between financial liberalisation and economic growth. On South Africa, Odhiambo (2010a) finds strong support for the positive impact of interest rate reforms on financial 
development, but that financial development does not Granger cause investment and economic growth. Also, on the study of four Southern African Development Community countries - Lesotho, South Africa, Tanzania and Zambia, Odhiambo (2011) finds that although financial liberalisation leads to financial development in all the study countries, it Granger causes economic growth only in Zambia and in the other countries it is economic growth which induces the development of the financial sector. On Pakistan, Hye and Wizarat (2013) find a positive relationship between the financial liberalisation index and economic growth in the short-run and further conclude that the impact of real interest rates on economic growth is negative and significant in the long-run.

\section{Empirical model and method of analysis}

\subsection{The empirical model}

A simplified theoretical framework of the McKinnon (1973) and Shaw (1973) hypothesis is that the creation of higher interest rates leads to increases in savings from depositors, increases in financial intermediation and improved efficiency of using saving (i.e. generating credits). That is, with high interest rates, funds are pooled from savers which allow banks to channel such funds to the private sector in the form of credit. Hence, higher positive real interest rates are warranted to build up real money balances, increase financial intermediation and unification of financial markets, thereby ensuring an efficient utilisation of resources, particularly the scarce capital. The complementarity between money and capital accumulation will, therefore, continue to exist as long as the real positive interest rate does not exceed the real rate of return on investment (Odhiambo 2010b). Such that credit is a function of interest rate (the financial reform indicator) as stated in Equation (1):

$$
C R_{t}=f\left(I N T_{t}\right)
$$

where $C R_{t}$ denotes credits and $I N T_{t}$ is the rate of interest.

An extensive time series literature examines the finance-growth relationship using a variety of time series methods. These studies frequently use the Johansen test of cointegration, Granger-type causality tests and vector autoregressive procedures to examine the relationships between macroeconomic variables and economic growth (Alege and Osabuohien 2013; Alege and Okodua 2014), or specifically the nature of the finance-growth relationship (Edo 2012). Over time research has progressed using better measures of financial development, employing more powerful econometric techniques and by examining individual countries in greater depth (Shan 2003; Shan and Jianhong 2006; Soultanaeva 2010).

Our research hypothesis is analysed within the autoregressive distributed lag (ARDL) ${ }^{2}$ model framework. This approach has three advantages in comparison with other previous and traditional cointegration methods. First, the ARDL does not need all the variables under study to be integrated of the same order and can be applied when the underlying variables are integrated of order one, order zero or mixed. Secondly, the ARDL test is relatively more efficient in the case of small and finite sample data sizes. Lastly, by applying the ARDL technique the long-run unbiased estimates of the model are obtained (Harris and Sollis 2003; Belloumi 2014; Kripfganz and Schneider 2016). There are, therefore, important econometric advantages in examining the relationship between financial reforms and credit 
growth within the framework of an ARDL model. Thus, following Kripfganz and Schneider (2016), we modify the ARDL $(p, q, \ldots, q)$ model as:

$$
\boldsymbol{Y}_{t}=\varphi_{0 i}+\sum_{i=1}^{p} \delta_{i} \boldsymbol{Y}_{t-i}+\sum_{i=0}^{q} \beta_{i}^{\prime} \boldsymbol{X}_{t-i}+\boldsymbol{\varepsilon}_{i t}
$$

where $\boldsymbol{Y}_{t}$ represents either credit growth or real interest rate; and the variables in $\left(\boldsymbol{X}_{t}^{\prime}\right)^{\prime}$ are allowed to be purely $I(0)$ or $I(1)$ or co-integrated; $\varepsilon_{t}=\left(\varepsilon_{C R t}, \boldsymbol{\varepsilon}_{R R t}\right) ; \beta$ and $\delta$ are coefficients; $\phi$ is the constant; $p, q$ are optimal lag orders; $\varepsilon_{i t}$ is a vector of the error terms - unobservable zero mean white noise vector process (serially uncorrelated or independent).

\subsection{The data and a priori expectations}

This study uses annual data on six (6) variables - domestic credit to the private sector/GDP, real interest rate, inflation rate, financial system deposits/GDP, GDP per capita growth and growth rate of gross fixed capital formation (investment). The data span is from 1980 to 2016 and all indicators are obtained from the World Development Indicators of the World Bank (2017) except financial system deposits sourced from World Bank (2016). Credit growth $(C R)$ is proxied by domestic credit to the private sector provided by financial institutions as a percentage of GDP. It measures the volume of credit facilities from the financial sector availed to households and firms excluding public sector credits. It is also a measure of financial depth and stability. The real interest rate $(R R)$ is the lending rate adjusted for inflation as measured by the GDP deflator, it is the financial reform variable. The inflation rate (INF) as measured by the consumer price index reflects the annual percentage change in the average food basket of a consumer. Financial system deposits (FSD) a measure of financial depth reflects the volume of financial liquidity; the GDP per capita growth (PCGr) is the measure of economic growth while the growth rate of gross fixed capital formation (INV) captures the growth rate of gross domestic investment and real sector activities.

On the a priori expectations, with $C R$ as the dependent variable, there is no consensus from the empirical literature on the direction of the impact of $R R$. To some, a high interest rate is inimical to growth (Fry 1980; Roubini and Sala-I-Martin 1992; De Gregorio and Guidotti 1995) while to some, it stimulates growth (International Monetary Fund 1983), hence, the relationship is ambiguous. INF is expected to have a positive relationship with $C R$ and a negative relationship with $R R$ as rising inflation causes the real rate of return to fall. FSD is expected to have a positive coefficient because with more loanable funds at the disposal of financial intermediaries, credit should increase and also with increased liquidities should drive down interest rates if loanable funds are not matched with credit creation, likewise the need for more funds may influence rates to rise. Increase in $P C G r$ stimulates the need for more credit which may exert a positive effect on the real interest rate. $I N V$ is expected to have a positive effect on $C R$ as the need for business expansion creates the demand for loans.

The theoretical justifications for the inclusion of the explanatory variables are summarised thus. The use of the interest rate as the financial reform variable stems from the Keynesian and neoclassical financial liberalisation theories (Molho 1986) to the theoretical and analytical frameworks of McKinnon (1973) and Shaw (1973). According to these schools of thought, deposit interest rate liberalisation allows savers to switch some of their savings 
Table 1. Descriptive statistics and correlation matrix.

\begin{tabular}{lrrrrrr}
\hline Variables & Dom. Crdt. & Real Int. & \multicolumn{1}{c}{ Inf. } & Fin. Sys. & PC Gr. & \multicolumn{1}{c}{ Inv. } \\
\hline Mean & 25.637 & -0.200 & 19.343 & 17.372 & 0.900 & 2.975 \\
Standard deviation & 11.695 & 16.371 & 17.515 & 5.485 & 7.316 & 23.264 \\
Minimum & 4.909 & -43.573 & 5.382 & 8.480 & -15.455 & -35.997 \\
Maximum & 48.672 & 25.282 & 72.836 & 34.660 & 30.357 & 59.388 \\
Domestic credit & 1.000 & & & & & \\
Real interest rate & -0.096 & 1.000 & & & & \\
Inflation & 0.238 & -0.477 & 1.000 & & & \\
Financial sys. dep. & 0.662 & 0.203 & -0.221 & 1.000 & & \\
GDP per capita growth & -0.488 & 0.361 & -0.093 & -0.200 & 1.000 & \\
Investment growth & -0.441 & 0.198 & -0.218 & -0.142 & 0.325 & 1.000 \\
\hline
\end{tabular}

Source: Authors' computations.

from unproductive real assets to financial assets thereby leading to an increase in financial deepening, hence expanding the supply of credit in the economy, investment and economic growth. However, for this study, we use the real interest rate to ascertain the behaviour of domestic credit. Nigeria being an inflation-targeting economy justifies the inclusion of the variable in addition to being the second component of the real interest rate. On the inclusion of financial system deposits, the McKinnon-Shaw hypothesis posit that increase in the pool of funds from depositors' i.e. loanable funds encourages more financial intermediation (i.e. use of savings). Thus, increase in financial system deposits imply more loanable funds available for financial intermediation and hence more supply of credit. Per capita GDP growth is included to capture economic growth. This is because in the finance-growth literature there are two main hypotheses: the demand following hypothesis (i.e. economic growth leads financial development) and the supply leading hypothesis (finance leads growth). The former holds that as the economy develops, it creates the need for finance (need for credit) to accelerate growth (Robinson 1952; Patrick 1966; Chuah and Thai 2004) while the latter is of the view that financial system development drives economic growth. That is, under a supply leading response, the development of financial institutions induces the development of the real sector of the economy (Spears 1992; King and Levine 1993; Odedokun 1996; Xu 2000). Hence, our inclusion of GDP per capita growth which is the proxy for economic size in the model. Lastly, gross fixed capital formation captures the real sector. Table 1 shows the summary statistics of each variable and their correlation matrix.

The correlation matrix which reflects the observed associations among the variables, reveals that there is no exact linear dependence among them. However, the regression analysis will show their exact causal relationships.

\section{Results and discussion}

\subsection{Unit root tests}

The empirical investigation of any analysis starts with the graphical illustration of the variables (Figure 1) in order to visualise their time series properties as it is imperative that these variables be stationary in order to avoid obtaining spurious results. Graphical analysis reveals that the real interest rate looks stationary around its mean while domestic credit and financial system deposits exhibit unit roots.

However, we subject all six variables to test using the Phillips-Perron (PP) test and the Dickey-Fuller generalised least squares ${ }^{3}$ (DF-GLS) test. For these tests, the null hypothesis 


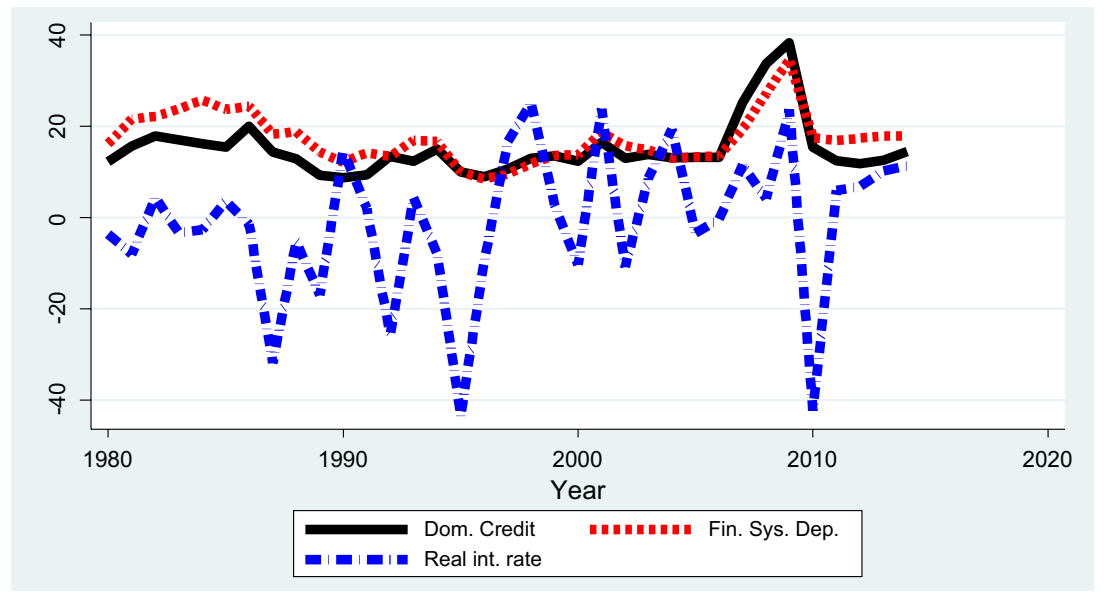

Figure 1. Trend of credit growth, real interest rate and financial systems deposits (1980-2016). Source: Authors' computation from World Bank (2017) and World Bank (2016).

Table 2. DF-GLS (with trend) and PP unit root tests.

\begin{tabular}{|c|c|c|c|c|c|c|}
\hline \multirow[b]{2}{*}{ Variables } & \multicolumn{3}{|c|}{ DF-GLS } & \multicolumn{3}{|c|}{$\mathrm{PP}$} \\
\hline & Level & 1st diff. & Decision & Level & 1st diff. & Decision \\
\hline Domestic Credit & -2.920 & $-3.735^{b}$ & $I(1)$ & -3.010 & $-5.470^{\mathrm{a}}$ & I(1) \\
\hline Real Interest Rate & $-6.581^{a}$ & - & $I(0)$ & $-6.417^{a}$ & - & $I(0)$ \\
\hline Inflation Rate & $-3.046^{c}$ & - & $I(0)$ & -3.100 & $-5.486^{a}$ & $I(1)$ \\
\hline Financial Sys. Dep. & -2.674 & $-4.096^{a}$ & $I(1)$ & -2.579 & $-5.728^{a}$ & I(1) \\
\hline GDP Per capita Gr. & $-5.106^{a}$ & - & $I(0)$ & $-5.180^{\mathrm{a}}$ & - & $I(0)$ \\
\hline Investment Growth & -2.251 & $-3.349^{b}$ & $I(1)$ & $-5.235^{\mathrm{a}}$ & - & $I(0)$ \\
\hline
\end{tabular}

a,b,cDenote statistical significance at 1, 5 and 10\% levels, respectively. Estmations augmented with lag structures obtained from Bayesian Information Criterion (BIC) using the varsoc routine in Stata. *Interpolated critical values from Elliot, Rothenberg, and Stock (1996).

Source: Authors' computations.

of a unit root cannot be rejected if the test statistic is insignificant. These results are shown in Table 2.

From the results shown in Table 2, our study sample is a mix of $I(0)$ and $I(1)$ series with both tests consistent with the results on domestic credit, real interest rate, financial system deposits and GDP per capita being $I(1)$ while the results on inflation rate and investment growth are divergent.

\subsection{Bounds testing for cointegration}

Having established that the variables are integrated of different orders, we proceed to analyse if there exists any cointegration among the variables using the ARDL bounds test approach (based on the error correction representation) as developed by Pesaran, Shin, and Smith (2001). The bounds test is mainly based on the joint $F$-statistic whose asymptotic distribution is non-standard under the null hypothesis of no cointegration (i.e. $\beta_{1}=\beta_{2}=\beta_{3}=$ $\beta_{4}=\beta_{5}=\beta_{6}=0$ ) against the alternative hypothesis of a cointegrating relationship (i.e. $\beta_{1} \neq$ $\beta_{2} \neq \beta_{3} \neq \beta_{4} \neq \beta_{5} \neq \beta_{6} \neq 0$ ). Under the bounds test, it is assumed that the model comprises 
Table 3. Bounds testing results.

\begin{tabular}{|c|c|}
\hline Cointegration hypotheses & F-statistics \\
\hline 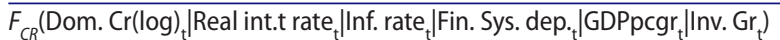 & $4.437^{b}$ \\
\hline 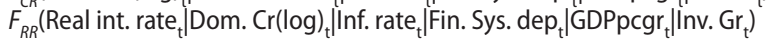 & $26.595^{\mathrm{a}}$ \\
\hline
\end{tabular}

both $I(0)$ and $I(1)$ variables and two levels of critical values are obtained. The first level is calculated on the assumption that all variables included in the ARDL model are integrated of order zero, while the second one is calculated on the assumption that the variables are integrated of order one. The procedure is to estimate the equation by ordinary least squares and test for joint significance of the lagged levels of the variables. The null hypothesis of no cointegration is rejected if the F-statistic is higher than the critical value of both the $I(0)$ and $I(1)$ regressors, and not rejected if otherwise (Belloumi 2014). The use of this test is guided by the short data span (37 observations), we therefore use the critical values given in Narayan $(2004,2005)$. The results are shown in Table 3.

The comparisons indicate that the null hypotheses of no cointegration is rejected at the $5 \%$ and $1 \%$ levels, respectively, as there are unique cointegrating relationships among the variables in the models and that the long-run forcing variables are inflation rate, financial system deposits, growth rate of per capita GDP and investment growth in both relationships. For instance, when the real interest rate is the dependent variable, the calculated $F_{R R}$ (Realint. rate $_{t} \mid$ Dom.credit ${ }_{t} \mid$ Inf.rate ${ }_{t} \mid$ Fin.systemdep $\left.{ }_{t}\left|\operatorname{GDPpcgr}_{t}\right| \operatorname{Invgr}_{t}\right)=26.595$ which is higher than the upper bound critical value of 5.419 at the $1 \%$ level. This indicates that there is a cointegrating relationship among the variables and the null hypothesis of no cointegration is rejected. Likewise another cointegrating relationship exists at the $5 \%$ significance level when domestic credit is the dependent variable. These results indicate that in both relationships, inflation rate, financial system deposits, growth rate of per capita GDP and investment growth are the forcing variables that move first when a common stochastic shock hits the system. The implication of the above finding is that: domestic credit and real interest rate follow changes in these indicators.

\section{3. $A R D L$ and ECM results}

Having established cointegration, we proceed to analyse the long-run relationships and short-run dynamics using a log-level ARDL error correction representation approach, and specify same as:

$$
\begin{gathered}
\Delta \ln C R_{t}=\alpha_{0}-\gamma\left(\ln C R_{t-1}-\theta \boldsymbol{X}_{t}\right)+\sum_{i=1}^{p-1} \omega_{\ln C R i} \Delta \ln C R_{t-1}+\sum_{i=0}^{q-1} \omega_{X i} \Delta \boldsymbol{X}_{t-i}+\varepsilon_{1 t} \\
\Delta R R_{t}=\alpha_{0}-\gamma\left(R R_{t-1}-\theta \boldsymbol{X}_{t}\right)+\sum_{i=1}^{p-1} \omega_{R R i} \Delta R R_{t-1}+\sum_{i=0}^{q-1} \omega_{X i} \Delta \boldsymbol{X}_{t-i}+\varepsilon_{2 t}
\end{gathered}
$$

where $\Delta$ is the difference operator; $\gamma=1-\sum_{j=1}^{p} \delta_{i}$ is the speed of adjustment coefficient; $\theta=\frac{\sum_{j=0}^{q} \beta_{j}}{\alpha}$ is the long-run coefficient. 
Equations (3) and (4) state that $\Delta \ln C R(\Delta R R)$ depends on its lag, the differenced explanatory variables and also on the equilibrium error term. If the latter is nonzero, then the model is out of equilibrium. Since $\gamma$ is expected to be negative, its absolute value decides how quickly equilibrium is restored. The results are presented in Table 4 (log of domestic credit as the dependent variable) and Table 5 (real interest rate as the dependent variable).

In Table 4, the error correction term (denoted Adjustment, the first lag of domestic credit) is found to be negative and statistically significant $(-0.473)$. This term shows the speed of adjustment process to restore equilibrium following a shock in the long-run equilibrium relationship. A negative and significant error correction term implies how quickly variables return to equilibrium. A relatively high adjustment coefficient (in absolute term) indicates a faster adjustment process. For instance, this result implies that almost $47 \%$ of the

Table 4. Error correction results (Dep. variable: $\Delta$ Domestic Credit, log) ARDL (1 0010103 ).

\begin{tabular}{|c|c|}
\hline Constant & $0.467(1.23)$ \\
\hline \multicolumn{2}{|l|}{ Long-run estimates } \\
\hline Real interest rate & $0.035^{c}(2.06)$ \\
\hline Inflation rate & $0.026^{\mathrm{a}}(2.94)$ \\
\hline Financial sys. dep. & $0.093^{a}(3.75)$ \\
\hline GDP per capita Gr. & $-0.074^{b}(-2.29)$ \\
\hline Investment growth & $0.010(0.76)$ \\
\hline \multicolumn{2}{|l|}{ Adjustment } \\
\hline Dom. Credit, log_1 & $-0.457^{b}(-2.84)$ \\
\hline \multicolumn{2}{|l|}{ Short-run estimates } \\
\hline$\Delta$ Financial Sys. Dep. & $-0.028(-1.19)$ \\
\hline$\Delta$ Investment Growth & $0.0003(0.09)$ \\
\hline$\Delta$ Investment Gr._1 & $0.004(1.54)$ \\
\hline$\Delta$ Investment Gr._2 & $0.007^{\mathrm{a}}(2.99)$ \\
\hline No. of Obs. & 30 \\
\hline$R^{2}$ & 0.809 \\
\hline
\end{tabular}

Notes: Numbers in parentheses are $t$-statistics based on White heteroscedasticity-consistent standard errors. Statistical significance: a,b,c indicate 1, 5 and 10\% levels, respectively. The variables lag length (1 $\left.\begin{array}{llll}0 & 0 & 1 & 0\end{array}\right)$ ) for domestic credit model are Stata-generated using the 'varsoc' routine. $\Delta$ is the difference operator.

Source: Authors' computations.

Table 5. Error correction results (Dep. variable: $\Delta$ Real Interest Rate) ARDL (1 11010103$)$.

\begin{tabular}{|c|c|}
\hline Constant & $-4.019(-0.30)$ \\
\hline \multicolumn{2}{|l|}{ Long-run estimates } \\
\hline Dom. Credit, log & $8.915(1.48)$ \\
\hline Inflation Rate & $-0.452^{\mathrm{a}}(-4.24)$ \\
\hline Financial Sys. Dep. & $-0.914^{\mathrm{c}}(-1.86)$ \\
\hline GDP per capita Gr. & $1.226^{a}(4.07)$ \\
\hline Investment Growth & $-0.201(-1.26)$ \\
\hline \multicolumn{2}{|l|}{ Adjustment } \\
\hline Real Int Rate_1 & $-1.043^{a}(-10.24)$ \\
\hline \multicolumn{2}{|l|}{ Short-run estimates } \\
\hline$\Delta$ Dom. Credit, log & $8.060(1.22)$ \\
\hline$\Delta$ Financial Sys. Dep. & $2.652^{\mathrm{a}}(5.08)$ \\
\hline$\Delta$ Investment Growth & $0.056(0.42)$ \\
\hline$\Delta$ Investment Gr._1 & $-0.006(-0.06)$ \\
\hline$\Delta$ Investment Gr._2 & $-0.151(-1.70)$ \\
\hline No. of Obs. & 30 \\
\hline$R^{2}$ & 0.939 \\
\hline
\end{tabular}

Notes: Numbers in parentheses are $t$-statistics based on White heteroscedasticity-consistent standard errors. Statistical sig-

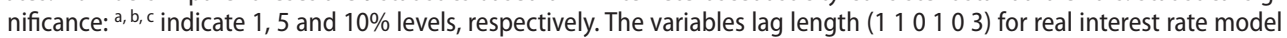
are Stata-generated using the 'varsoc' routine. $\Delta$ is the difference operator.

Source: Authors' computations. 
disequilibrium of the previous year's shocks are corrected back to the long-run equilibrium in the current year. Other results reveal that in the long-run, credit growth is positively related to the inflation rate (0.0259), financial liquidity (0.0932) and negatively to per capita GDP (-0.0735). These variables are strong predictors of credit growth. Most importantly for our purposes, we find that credit growth is positively and significantly linked to the measure of financial reform in the long-run. This effect is also economically significant as the point estimate implies that a $1 \%$ increase in the real interest rate leads to a rise of $0.03 \%$ in domestic credit, ceteris paribus. This evidences the positive impact of financial reform and further validates the McKinnon (1973) and Shaw (1973) hypothesis that higher interest rate causes increased financial intermediation evidenced by credit growth. It is reassuring that we are able to reproduce same with our approach. From the short-run coefficients, credit growth is strongly predicted by the second lag of investment growth (0.007). Lastly, the $R^{2}$ indicates that $81 \%$ variations in domestic credit are explained by the regressors.

The results shown in Table 5 are significantly different from those in Table 4 both in significance and magnitude. The adjustment term is larger $(-1.0432)$ suggesting that the rate of adjustment to long-run equilibrium is faster and that the real interest rate adjusts to its realisation with a lag correcting $104 \%$ of the discrepancy between the long-term and short-term real interest rate within the period. This coefficient is slightly below -1 but falls within the dynamically stable range (Pesaran, Shin, and Smith 1999; Loayza and Romain 2006) since it is not lower than -2 (that is, within the unit circle). This indicates that the feedback from financial reform is very effective in Nigeria and convergence to long-run equilibrium after a shock to the explanatory variables is instantaneous for the real interest rate (Narayan 2005). It also implies that the adjustment term produces dampened fluctuations around the equilibrium path of the real interest rate but convergence to long-run stable state is very rapid (Narayan and Smyth 2005).

For the long-run coefficients, the inflation rate $(-0.4517)$, financial liquidity $(-0.9136)$ and GDP per capita growth rate (1.2256) are strong predictors of interest rate with only the short-run coefficient on financial liquidity positive. Another important finding evidencing the McKinnon (1973) and Shaw (1973) hypothesis is that at higher inflation rate, the real rate of return falls. Again, the $R^{2}$ shows that $94 \%$ variations in the real interest rate are explained by the regressors. Overall, these results lend support to previous studies such as: Loayza and Romain (2004), Obamuyi and Olorunfemi (2011), Okoye and Eze (2013), Odhiambo (2010b, 2010a, 2011), Chipote, Mgxekwa, and Godza (2014), Cubillasa and González (2014) and Orji, Aguegboh, and Anthony-Orji (2015) that financial reforms have a positive influence on credit growth.

\subsection{Diagnostic tests results}

The last issue we address is related to the goodness of fit of the ARDL error correction models. For this purpose, series of diagnostic and stability tests were carried out. The diagnostic tests examine serial correlation, heteroscedasticity, conditional heteroscedasticity, Ramsey's RESET $^{4}$ test and normality. The results reported in Table 6 indicate that there are no challenges of misspecification, heteroscedasticity, higher-order autocorrelation or normality in the model. This implies that the results from our analyses are robust and reliable for making inferences. Also, the plot of the CUSUMSQ shows that the model is stable as the graph lies within the 5\% significance level boundaries (see Figure 2). 
Table 6. Diagnostic tests results.*

\begin{tabular}{lcl}
\hline Specification & Stat./p-values & \multicolumn{1}{c}{ Conclusion } \\
\hline Durbin-Watson (autocorrelation) & $2.122 / 1.899$ & No autocorrelation \\
Bruesch-Godfrey (autocorrelation) & $0.442 / 0.975$ & No higher-order autocorrelation \\
Bruesch-Pagan (heteroscedasticity) & $0.299 / 0.296$ & No heteroscedasticity \\
ARCH LM & $0.779 / 0.686$ & No conditional heteroscedasticity \\
Ramsey RESET (omitted variables) & $0.061 / 0.388$ & No omitted variables \\
Jarque-Bera (normality) & $0.864 / 0.973$ & Evidence of normality \\
\hline
\end{tabular}

*The $p$-values $x / y$ indicate results of when log of domestic credit/real interest rate is the dependent variable. The $d$-statistics used for Durbin-Watson.

Source: Authors' computations

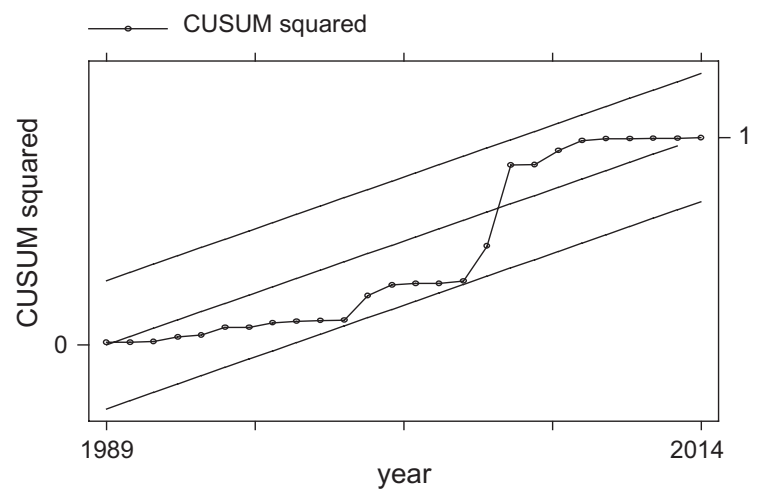

Figure 2. Plot of CUSUMSQ for Model Stability at $5 \%$ level of Significance. Source: Authors' computation.

\section{Conclusion and policy implications}

The nexus between financial reform and economic growth has received some attention in extant studies. However, there is a dearth of knowledge regarding how such mechanisms operate with respect to channels of influence. This study extends the frontiers of knowledge in this area by examining the impact of financial reforms on credit growth in Nigeria. This objective was achieved by employing the ARDL bounds testing technique in analysing time series data spanning a period of 37 years (1980-2016). The empirical analysis is based on the assumption that the efficiency of the use of savings is directly related to a high and positive interest rate. We find evidences to the McKinnon (1973) and Shaw (1973) hypothesis that (1) at higher interest rate, financial intermediation improves as evidenced by credit growth, and (2) at higher inflation rate, the real rate of return falls. In addition, the inflation rate, financial system deposits and per capita GDP are strong predictors of both domestic credit and the real interest in the long-run, though asymmetrically. The short-run effects on these variables are also indicator-specific with investment growth having a significant positive impact on domestic credit while the real interest rate is positively related to financial liquidity. Given these results, we conclude that policies that will further increase credit be pursued by the government in order to revamp activities in the real sector and improve the efficiency of financial intermediation. Subject to data availability, the need to test the extent of financial intermediation, that is, the responsiveness of domestic credit to other variants of interest rate viz lending and deposit rates is important. This can be taken up in subsequent research. 


\section{Notes}

1. Credit is measured as domestic credit to the private sector/GDP. This does not include loans and advances to the public sector.

2. The optimal lag length for the model is 4 . Using the Stata routine 'varsoc', it is obtained from the choice of Bayesian information criterion, Hannan-Quinn information criterion and Akaike information criterion of which they all gave the same value, an indication that the model is well specified.

3. Proposed by Elliot, Rothenberg, and Stock (1996), it is essentially an augmented Dickey-Fuller test except that the time series is transformed via a generalised least squares (GLS) regression before performing the test. Elliott, Rothenberg, and Stock and later studies have shown that this test has significantly greater power than the previous versions of the augmented DickeyFuller test.

4. The null hypothesis of no omitted variables cannot be rejected at the $5 \%$ level with domestic credit as the dependent variable.

\section{Disclosure statement}

No potential conflict of interest was reported by the authors.

\section{Funding}

This work was supported by the Covenant University Centre for Research, Innovation and Discovery (CUCRID).

\section{References}

Adam, M. A. 2011. "Financial Openness Induced Growth and Poverty Reduction." The International Journal of Applied Economics and Finance 5 (1): 75-86.

Adelakun, O. J. 2010. "Financial Sector Development and Economic Growth in Nigeria." International Journal of Economic Development Research and Investment 1 (1): 1-17.

Akingunola, R. O., A. A. Olusegun, B. Oluwaseyi, and S. G. Olusoji. 2013. "The Effect of the Financial Liberalisation on Economic Growth." International Journal of Academic Research in Economics and Management Sciences 2 (1): 2226-3624.

Alege, Philip O., and Henry Okodua. 2014. "International Competitiveness and Growth of the Nigerian Economy: A Structural VAR-Based Perspective." Research in Applied Economics 6 (4): 53-74.

Alege, Philip O., and E. S. C. Osabuohien. 2013. "G-Localization as a Development Model: Economic Implications for Africa." International Journal of Applied Economics \& Econometrics, Bangalore. India 21 (1): 41-72.

Balassa, Bela. 1990. "Financial Liberalization in Developing Countries." Edited by The World Bank Development Economics. Washington, DC: Office of the Vice President.

Bassey, B., P. Bessong, and C. Effiong. 2012. “The Effect of Monetary Policy on Demand for Money in Nigeria." Interdisciplinary Journal of Contemporary Research in Business 4 (7): 430-439.

Belloumi, Mounir. 2014. "The Relationship between Trade, FDI and Economic Growth in Tunisia: An Application of the Autoregressive Distributed Lag Model." Economic Systems 38 (2): 269-287.

Chandar, N., D. K. Patro, and A. Yezegel. 2009. "Crises, Contagion and Cross-listing." Journal of Banking and Finance 33: 1709-1729.

Chipote, Precious, Bahle Mgxekwa, and Praise Godza. 2014. "Impact of Financial Liberalization on Economic Growth: A Case Study of South Africa." Mediterranean Journal of Social Sciences 5 (23): $1-8$.

Chuah, Hong Leng, and Van-can Thai. 2004. "Financial Development and Economic Growth: Evidence from Causality Tests for the GCC Countries.” IMF Working Paper Wp/04/XX: 1-47. 
Chung, K. H., W. T. Smith, and T. L. Wu. 2009. “Time Diversification: Definitions and Some Closedform Solutions.” Journal of Banking and Finance 33: 1101-1111.

Cubillasa, Elena, and Francisco González. 2014. "Financial Liberalization and Bank Risk-taking: International Evidence." Journal of Financial Stability 11: 32-48.

De Gregorio, J., and P. E. Guidotti. 1995. "Financial Development and Economic Growth." World Development 23 (3): 433-448.

Edo, Samson E. 2012. "Performance of Liabilities Accruing from Liberalization of the Banking Sector in Nigeria." The Review of Finance and Banking 4 (2): 1-12.

Efobi, U. R., E. S. Osabuohien, and S. Oluwatobi. 2014. "One Dollar, One Bank Account: Remittance and Bank Breadth in Nigeria." Journal of International Migration and Integration 16 (3): 761-781.

Efobi, U. R., I. Beecroft, and E. S. Osabuohien. 2014. "Access to and Use of Bank Services in Nigeria: Micro-econometric Evidence." Review of Development Finance 4: 104-114.

Egwakhe, A. J., and E. S. C. Osabuohien. 2009. "Positioning Nigerian Service Sector towards Vision 2020: Stylized Facts from Banking Sub-sector." Pakistan Economic and Social Review 47 (2): 139156.

Elliot, G., T. J. Rothenberg, and J. H. Stock. 1996. "Efficient Tests for an Autoregressive Unit Root." Econometrica 64: 813-836.

Fry, M. J. 1980. "Savings, Investment, Growth and the Cost of Financial Repression.” World Development 8 (4): 317-327.

Harris, R., and R. Sollis. 2003. Applied Time Series Modeling and Forecasting. West Sussex: Wiley.

Hye, Qazi Muhammad Adnan, and Shahida Wizarat. 2013. "Impact of Financial Liberalization on Economic Growth: A Case Study of Pakistan." Asian Economic and Financial Review 3 (2): 270-282.

International Monetary Fund, Research Dept. 1983. Interest Rate Policies in Developing Countries. Vol. 22. International Monetary Fund.

Khalaf, A. H. 2011. "Impact of Financial Liberalization on Financial Depth in Iraq." The Review of Finance and Banking 3 (2): 67-78.

King, R. G., and R. Levine. 1993. "Finance and Growth: Schumpeter Might Be Wright.” Quarterly Journal of Economics 108 (3): 713-737.

Kripfganz, Sebastian, and Daniel C. Schneider. 2016. "ARDL: Stata Module to Estimate Autoregressive Distributed Lag Models.” Stata Conference, Chicago, July 29.

Loayza, Norman, and Romain Rancière. 2006. "Financial Development, Financial Fragility and Growth." Journal of Money, Credit and Banking 38 (6): 1051-1076.

McKinnon, R. I. 1973. Money and Capital in Economic Development. Washington, DC: Brookings Institution.

Molho, Lazarus. 1986. Interest Rate, Savings and Investment in Developing Countries: A Reexamination of the McKinnon-Shaw Hypothesis. IMF Staff Papers 33 (1): 90-111.

Narayan, Paresh Kumar. 2004. "Reformulating Critical Values for the Bounds F -statictics Approach to Cointegration: An Application to the Tourism Demand Model for Fiji." Department of Economics Discussion Papers No. 02/04, Monash University, Melbourne, Australia.

Narayan, Paresh Kumar. 2005. "The Saving and Investment Nexus for China: Evidence from Cointegration Tests.” Applied Economics 37 (17): 1979-1990. doi:10.1080/00036840500278103.

Narayan, Paresh Kumar, and Russell Smyth. 2005. "What Determines Migration Flows from Lowincome to High-income Countries? An Empirical Investigation of Fiji-U.S. Migration 1972-2001." Contemporary Economic Policy 24 (2): 332-342.

Obamuyi, Tomola M., and Sola Olorunfemi. 2011. "Financial Reforms, Interest Rate Behaviour and Economic Growth in Nigeria." Journal of Applied Finance \& Banking 1 (4): 39-55.

Odedokun, M. O. 1996. "Alternative Econometric Approaches for Analyzing the Role of the Financial Sector in Economic Growth: Time-series Evidence from LDCs." Journal of Development Economics 50 (1): 119-146.

Odhiambo, Nicholas M. 2010a. "Interest Rate Deregulation, Bank Development and Economic Growth in South Africa: An Empirical Investigation." International Business \& Economics Research Journal 9 (11): 1-12. 
Odhiambo, Nicholas M. 2010b. "Interest Rate Reforms and Credit Allocation in Tanzania: An Application of the ARDL Bounds Testing Approach." International Business \& Economics Research Journal 9 (5): 23-32.

Odhiambo, Nicholas M. 2011. "The Impact of Financial Liberalisation in Developing Countries: Experiences from Four SADC Countries." Organisation for Social Science Research in Eastern and Southern Africa (OSSREA), Addis Ababa.

Okoye, Victor, and Onyekachi Richard Eze. 2013. "Effects of Bank Lending Rate on the Performance of Nigeria Deposit Money Banks." International Journal of Business and Management Review 1 (1): $34-43$.

Olofin, Sam O., and Udoma J. Afangideh. 2008. "Financial Structure and Economic Growth in Nigeria: A Macro Econometric Approach.” Nigeria Journal of Securities and Finance 13 (1): 1-27.

Omankhanlen, Alex Ehimare. 2012. "The Financial Sector Reforms and Their Effect on the Nigerian Economy." Economy Transdisciplinarity Cognition 15 (2): 45-57.

Orji, Anthony, Ekene Aguegboh, and Onyinye I. Anthony-Orji. 2015. "Real Sector Output and Financial Liberalisation in Nigeria." Journal of Infrastructure Development 7 (2): 136-150.

Osabuohien, E. S. 2008. "ICT and Nigerian Banks' Reforms: Analysis of Anticipated Impacts in Selected Banks." Global Journal of Business Research 2 (2): 67-76.

Osuagwu, E. S., and N. Nwokoma. 2017. "Empirical Assessment of the Competitive Conduct of Nigerian Banks in a Post-consolidation Era." Research in International Business and Finance 41: $412-422$.

Patrick, H. T. 1966. "Financial Development and Economic Growth in Underdeveloped Countries." Economic Development and Cultural Change 14 (1): 174-189.

Pesaran, M. Hashem, Yongcheol Shin, and Ron P. Smith. 1999. "Pooled Mean Group Estimation of Dynamic Heterogenous Panels.” American Statistical Association 94 (446): 621-634.

Pesaran, M. Hashem, Yongcheol Shin, and Ron P. Smith. 2001. "Bounds Testing Approaches to the Analysis of Level Relationship." Journal of Applied Econometrics 16: 289-326.

Robinson, Joan 1952. "The Generalization of the General Theory." In The Rate of Interest and Other Essays. London: McMillian.

Roubini, N., and X. Sala-I-Martin. 1992. "Financial Repression and Economic Growth." Journal of Development Economics (Amsterdam) 39 (1): 5-30.

Shan, Jordan. 2003. "Financial Development and Economic Growth: The Empirical Evidence from China." Proceedings of the 15th Annual Conference of the Association for Chinese Economics Studies Australia (ACESA), Melbourne.

Shan, Jordan, and Qi Jianhong. 2006. "Does Financial Development Lead Economic Growth? The Case of China." Annals of Economics and Finance 7 (1): 197.

Shaw, E. S. 1973. Financial Deepening in Economic Development. New York, NY: Oxford University Press.

Shittu, Ayodele Ibrahim. 2012. "Financial Intermediation and Economic Growth in Nigeria." British Journal of Arts and Social Sciences 4 (2): 1-16.

Soultanaeva, Albina. 2010. "Financial Intermediation and Economic Growth: Evidence from the Baltic Countries." Umeå Economic Studies 817: 1-11.

Spears, A. 1992. "The Role of Financial Intermediation on Economic Growth in SSA." Canadian Journal of Development Studies 13: 361-380.

Taylor, L. 1988. Varieties of Stabilization Experience: Towards Sensible Macroeconomics in the Third World. Oxford: Clarendon Press.

Wijnbergen, S. 1982. "Stagflation Effect on Monetary Stabilization Policies: A Quantitative Analysis of South Korea." Journal of Development Economics 10 (Jun.):133-169.

World Bank. 2016. World Bank Global Financial Development Database. World Bank.

World Bank. 2017. World Development Indicators. Washington, DC: World Bank.

$\mathrm{Xu}$, Zhenhui. 2000. "Financial Development, Investment, and Economic Growth." Economic Inquiry 38 (2): 331-344. 